\title{
Essential Roles of Efferent Duct Multicilia in Male Fertility
}

\author{
Mohammed Hoque ${ }^{1}$, Eunice N. Kim ${ }^{1}$, Danny Chen ${ }^{2} \mathbb{D}$, Feng-Qian Li $^{2}$ and Ken-Ichi Takemaru ${ }^{1,2, *}$ \\ 1 Molecular and Cellular Biology Graduate Program, Stony Brook University, Stony Brook, NY 11794, USA; \\ hoque.mohammed@stonybrook.edu (M.H.); eunice.kim.2@stonybrook.edu (E.N.K.) \\ 2 Department of Pharmacological Sciences, Stony Brook University, Stony Brook, NY 11794, USA; \\ danny.chen@stonybrook.edu (D.C.); feng-qian.li@stonybrook.edu (F.-Q.L.) \\ * Correspondence: ken-ichi.takemaru@stonybrook.edu
}

Citation: Hoque, M.; Kim, E.N.; Chen, D.; Li, F.-Q.; Takemaru, K.-I. Essential Roles of Efferent Duct Multicilia in Male Fertility. Cells 2022, 11, 341. https://doi.org/10.3390/ cells11030341

Academic Editors: Zhibing Zhang, Zine Eddine Kherraf and Shuiqiao Yuan

Received: 10 December 2021

Accepted: 18 January 2022

Published: 20 January 2022

Publisher's Note: MDPI stays neutral with regard to jurisdictional claims in published maps and institutional affiliations.

Copyright: () 2022 by the authors Licensee MDPI, Basel, Switzerland. This article is an open access article distributed under the terms and conditions of the Creative Commons Attribution (CC BY) license (https:// creativecommons.org/licenses/by/ $4.0 /)$.

\begin{abstract}
Cilia are microtubule-based hair-like organelles on the cell surface. Cilia have been implicated in various biological processes ranging from mechanosensation to fluid movement. Ciliary dysfunction leads to a plethora of human diseases, known as ciliopathies. Although non-motile primary cilia are ubiquitous, motile multicilia are found in restricted locations of the body, such as the respiratory tract, the oviduct, the efferent duct, and the brain ventricles. Multicilia beat in a whip-like motion to generate fluid flow over the apical surface of an epithelium. The concerted ciliary motion provides the driving force critical for clearing airway mucus and debris, transporting ova from the ovary to the uterus, maintaining sperm in suspension, and circulating cerebrospinal fluid in the brain. In the male reproductive tract, multiciliated cells (MCCs) were first described in the mid-1800s, but their importance in male fertility remained elusive until recently. MCCs exist in the efferent ducts, which are small, highly convoluted tubules that connect the testis to the epididymis and play an essential role in male fertility. In this review, we will introduce multiciliogenesis, discuss mouse models of male infertility with defective multicilia, and summarize our current knowledge on the biological function of multicilia in the male reproductive tract.
\end{abstract}

Keywords: cilia; multiciliated cells; efferent ducts; spermatogenesis; fertility

\section{Introduction}

Cilia are microtubule-based, tiny hair-like organelles that extend from the apical surface of many different cell types [1-3]. Extensive work over the last few decades has revealed that cilia regulate a wide range of biological processes during development and adult homeostasis. Cilia are broadly classified into two types according to their microtubule composition: non-motile primary cilia with a $9+0$ microtubule arrangement and motile multicilia with a $9+2$ arrangement. The primary cilia in the embryonic node are a notable exception to this rule [4,5]. Nodal cilia, which are responsible for the establishment of the left-right body axis, have a $9+0$ microtubule arrangement but show motility. The ciliary axoneme, which is composed of microtubule bundles with associated proteins, is surrounded by a specialized ciliary membrane that is continuous with the plasma membrane but has distinct properties with unique lipid and receptor compositions [6,7]. Primary cilia are present on many different cell types in the human body and play key roles in mechanosensation, photoreception, and various intracellular signaling pathways, including hedgehog $(\mathrm{Hh})$, platelet-derived growth factor (PDGF), and G-protein-coupled receptor (GPCR) pathways [1,2]. In contrast, multicilia are found in limited locations in the human body, such as epithelial cells lining the respiratory tract, the female and male reproductive tracts, and the brain ventricles. Multiciliated cells (MCCs) contain dozens to hundreds of motile cilia that beat in a whip-like motion. The synchronous motility of multicilia is achieved by dynein motors in an ATP-dependent manner. The force generated by the ciliary beating typically drives directional fluid flow, for example, to clear airway mucus and debris, transport ova from the ovary to the uterus [8], and circulate 
cerebrospinal fluid in the brain [9]. Sperm flagella are more complex, singular motile cilia that are important for swimming and fertilization $[10,11]$.

Cilia are assembled from mother centriole-derived basal bodies. In contrast to the daughter centriole, the mother centriole harbors accessory structures, including subdistal and distal appendages. The distal appendages (also called "transition fibers" at the ciliary base) are critical for the recruitment of small vesicles and subsequent docking of basal bodies to the plasma membrane [12-15]. Most ciliary proteins are imported from the cell body via polarized vesicle trafficking from the Golgi complex or endosomes [16,17]. The extension of a cilium and its maintenance require intraflagellar transport (IFT), a bidirectional transport system that tracks along the axonemal microtubules [18,19]. Although the mode of centriole generation differs, the formation of both primary cilia and multicilia follows a similar pathway as discussed in more detail below $[20,21]$.

Given the ubiquitous presence of cilia and their important roles in embryonic development and adult homeostasis, it is not surprising that genetic defects in the structure and function of cilia are associated with a host of human disorders, collectively known as ciliopathies $[2,3,22]$. Dysfunctional primary cilia have been linked to various diseases and syndromes, such as polycystic kidney disease (PKD), Joubert syndrome (JBTS), and Bardet-Biedl syndrome (BBS) $[3,23,24]$. Their clinical features are variable but include situs inversus, polydactyly, retinal degeneration, intellectual disability, obesity, and cystic lesions of the kidney, liver, and pancreas. On the other hand, defects in multicilia are most prominently associated with primary ciliary dyskinesia (PCD) [25-28]. PCD is a rare genetic disorder, affecting approximately 1:10,000-40,000 individuals. To date, over 50 causative genes have been reported, including various axonemal components and regulatory factors of axonemal assembly and MCC differentiation $[11,27,29]$. PCD is characterized by recurrent respiratory infections, situs inversus, infertility, and more rarely hydrocephalus. Male infertility and sub-fertility are also common manifestations of PCD. Since sperm tail axonemes are structurally similar to motile cilia, malformations of sperm tails are commonly associated with PCD [11]. However, the exact effect of the gene mutations on the formation of sperm flagella remains poorly defined.

\section{Differentiation of Multiciliated Cells (MCCs)}

MCC differentiation is orchestrated by a coordinated cascade of regulators, including signaling pathways and transcription factors (Figure 1). Previous studies have demonstrated that the inhibition of the Notch and bone morphogenic protein (BMP) signaling pathways triggers a regulatory network of genes involved in the MCC fate determination of developing epithelia [30-33]. The upstream mechanisms that repress the Notch and BMP pathways are not fully understood. However, the microRNA clusters miR-34/miR-449 have been shown to play essential roles at multiple levels in multiciliogenesis by destabilizing target mRNAs $[34,35]$. The miR-34/miR-449 family includes the functionally redundant miRNA clusters $m i R-34 b / c$ and $m i R-449 a / b / c$, which are highly expressed in multiciliated tissues. In particular, miR-449 has been shown to promote MCC differentiation by directly repressing Notch1 and its ligand Delta-like 1 (DLL1) in progenitor cells [35-37].

Downstream of Notch inhibition, the MCC differentiation gene regulatory network is controlled by the coiled-coil Geminin family proteins Geminin (GMNN), Geminin coiledcoil domain-containing protein 1 (GEMC1), and MCIDAS (also known as multicilin or IDAS) [38-46]. Both GEMC1 and MCIDAS are master regulatory proteins that are necessary and sufficient for MCC differentiation [43,47]. Upon forming a ternary complex with the cofactor DP1 and transcription factors E2F4/5, GEMC1 is able to activate expression of MCIDAS and other downstream ciliary genes. MCIDAS also acts as a transcriptional activator by forming a complex with DP1 and E2F4/5 to stimulate gene expression essential for centriole biogenesis. Early multiciliogenesis factors that are downstream of GEMC1 and MCIDAS include deuterosome assembly protein 1 (DEUP1), MYB, cyclin O (CCNO), forkhead box J1 (FOXJ1), and RFX2/3 [41,43-45,48]. p73, another transcription factor downstream of MCIDAS, was found to activate expression of FOXJ1, RFX2/3, and miR- 
$34 b / c$ and nearly 50 other ciliary genes in mouse tracheal MCCs [49,50]. While the role of Geminin in MCC differentiation is less understood, it has been shown to act as an inhibitor of GEMC1 and MCIDAS function [40,44].

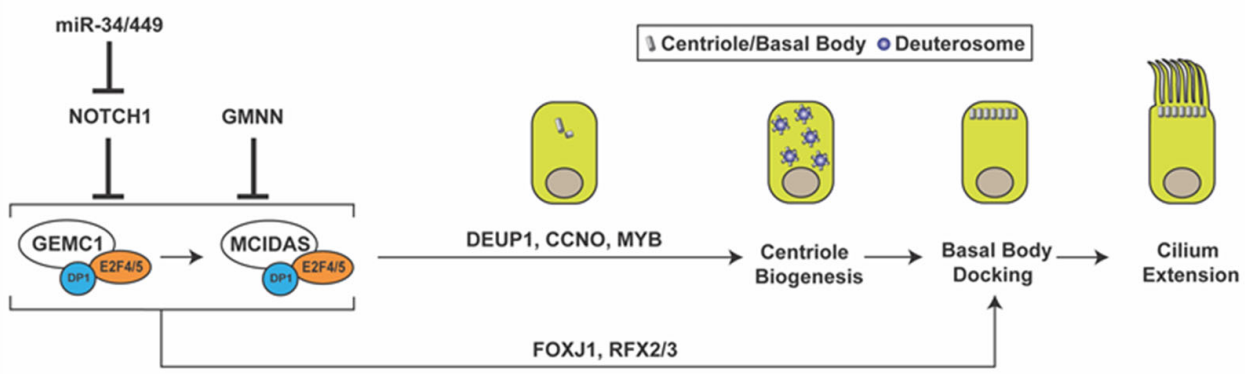

Figure 1. Multiciliated cell differentiation. Key factors and events for MCC differentiation are depicted. Repression of Notch signaling by miR-34/miR-449 triggers MCC differentiation. GEMC1 acts in a complex with E2F4/5 and DP1 to turn on MCIDAS and other ciliary genes necessary for centriole amplification, basal body docking, and cilium elongation. GMNN functions as an inhibitor of GEMC1 and MCIDAS. GMNN, geminin; GEMC1, geminin coiled-coil domain-containing protein 1; DEUP1, deuterosome assembly protein 1; CCNO, cyclin O; FOXJ1, forkhead box J1.

During MCC differentiation, the biogenesis of hundreds of centrioles occurs through two different pathways: the canonical centriolar pathway, which utilizes pre-existing centrioles for new centriole generation, and the de novo deuterosome-mediated pathway [51,52]. Although a small fraction of centrioles is produced via the canonical centriolar pathway, the majority are thought to be amplified from deuterosomes. Deuterosomes are electron-dense, fibrogranular structures that contain several proteins required for centriole amplification, such as DEUP1 and coiled-coil domain-containing 78 (CCDC78) [48,53,54]. Although research on the origins and molecular components of deuterosomes is still ongoing, it has been reported that deuterosomes are nucleated from existing centrioles or spontaneously synthesized in the cytoplasm [55-57]. A recent study questioned the need for the deuterosome in MCC centriole amplification, since MCCs lacking deuterosomes are able to amplify the correct number of centrioles with normal kinetics [58].

Following release from the deuterosome or centrosomal centriole, the nascent centrioles migrate to the apical cell surface, dock at the plasma membrane, and mature into basal bodies to initiate cilium assembly. For efficient basal body docking to occur, small vesicles are recruited to the distal appendages of centrioles and then fuse to form a larger membranous cap called the ciliary vesicle $[13,53,59]$. Subsequently, the ciliary vesicle flattens and forms a bilayer membranous sheath around the developing ciliary axoneme that merges with the cell membrane, allowing the elongating cilium to protrude from the apical cell surface. Vesicular trafficking during ciliogenesis has been studied mainly using mammalian cultured cells with primary cilia. In early stages of ciliogenesis, the fusion of small vesicles into the ciliary vesicle is mediated by the EPS-15 homology domain-containing (EHD) family of membrane-shaping proteins, EHD1 and EHD3 [52,60]. The small GTPase Rab11 then recruits and activates Rabin8, a guanine nucleotide exchange factor (GEF) for Rab8, in the vicinity of the centrosome. Rabin8, in turn, promotes the recruitment and local activation of Rab8 to facilitate ciliary membrane growth and vesicular transport of ciliary proteins into the cilium [61,62]. Rab8 and Rabin8 also interact with the distal appendage protein CEP164 (also known as NPHP15), which acts as a molecular bridge between the mother centriole and components of the ciliary membrane assembly machinery [12]. Our group demonstrated that, in airway MCCs, the 15-kDa coiled-coil protein Chibby1 (Cby1) plays an important role in ciliary vesicle formation and basal body docking (Figure 2) [13,63]. $\mathrm{Cby} 1^{-/-}$mice exhibit chronic upper airway infection, due to a markedly decreased number of multicilia and a complete absence of mucociliary clearance activity [63]. Cby1 and its interacting proteins localize to the base of cilia (Figure 2A). Cby1 is recruited to the distal appendages of basal bodies through its physical interaction with CEP164 and inter- 
acts with Rabin8 to facilitate the efficient assembly of ciliary vesicles (Figure 2B) $[13,64]$. Cby1 exists in a complex with the membrane remodeling proteins, Chibby1-interacting Bin/Amphiphysin/Rvs (BAR) domain-containing 1 and 2 (ciBAR1 and ciBAR2; previously known as FAM92A and FAM92B, respectively) $[64,65]$. Coexpression of ciBAR1 or ciBAR2 with Cby1 in mammalian cultured cells induces the formation of globular and tubular membrane structures, suggesting that the Cby1/ciBAR complex facilitates ciliogenesis through regulation of membrane-remodeling processes.

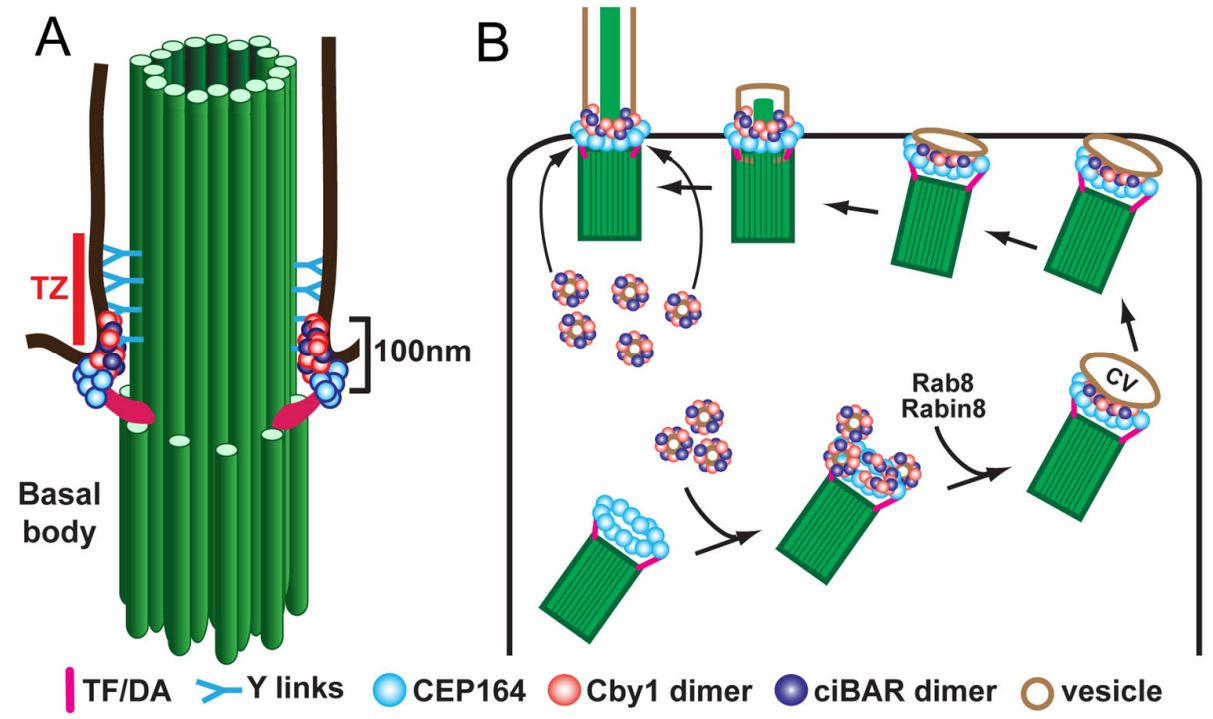

Figure 2. Model for localization (A) and function (B) of Cby1 and its associated proteins in airway MCCs. Cby1 clusters at the ciliary base as a ring with a diameter of $300 \mathrm{~nm}$ and a height of $100 \mathrm{~nm}$ [13]. Cby1 and its interactors are essential for the efficient docking of basal bodies to the apical membrane. $\mathrm{TZ}$, transition zone; $\mathrm{TF}$, transition fiber; $\mathrm{DA}$, distal appendage; $\mathrm{CV}$, ciliary vesicle.

The docking and planar polarization of basal bodies are controlled by the interplay between the planar cell polarity (PCP) pathway and the underlying actin and microtubule cytoskeleton [66-71]. The PCP pathway is a noncanonical Wnt pathway and has emerged as a critical regulator of MCC differentiation. In MCCs, the orientation of basal bodies is established via rotational polarity at the apical cell surface to enable synchronous beating of motile multicilia on each cell. PCP components localize to opposing membrane domains at the proximal and distal sides of cells $[68,69]$. The core PCP components include the evolutionarily conserved transmembrane proteins Frizzled, Van Gogh-like (Vangl, Van Gogh in Drosophila), Celsr (Flamingo in Drosophila) and cytoplasmic proteins Dishevelled, Prickle, and Inversin/Diversin (Diego in Drosophila). Mutations in the core PCP components lead to basal body docking defects and random orientation of basal bodies and ciliary beating in MCCs.

The extension and maintenance of cilia depend on the IFT machinery $[18,19]$. Along the cilium, anterograde IFT movement is mediated by kinesin-2 motors (from base to tip), whereas retrograde transport is powered by cytoplasmic dynein-2 (from tip to base). Fully developed cilia are highly dynamic and constantly undergo turnover with continuous transport of proteins and lipids in and out of cilia [72,73].

\section{Male Reproductive Tract and Passage of Spermatozoa through Efferent Ducts}

The male reproductive tract is composed of several highly convoluted tubular segments, each of which plays a crucial role in the development of fully functional spermatozoa (sperm) (Figure 3A). The testis, consisting of long convoluted seminiferous tubules, is the site of spermatogenesis [74-76]. From the testis, the spermatozoa are collected in the rete testis and are transported into the epididymis via the efferent ducts (EDs) $[77,78]$. The EDs contain specialized MCCs that prevent sperm from aggregating [79]. In the epididymis, 
sperm continue to mature and are finally stored in the cauda epididymis for eventual release via the vas deferens $[80,81]$.

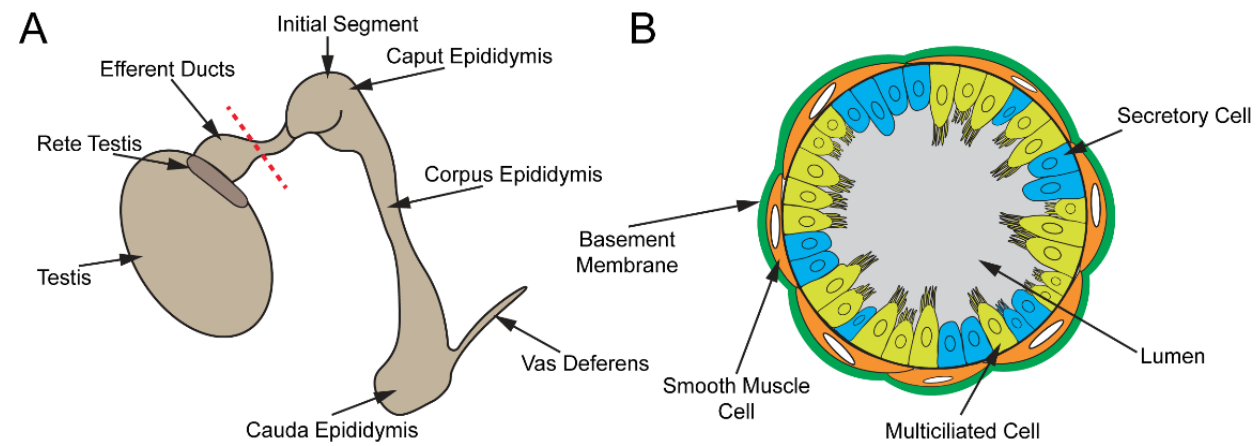

Figure 3. Male reproductive tract. (A) Cartoon schematic of the male reproductive tract. Sperm are produced in the seminiferous tubules of the testis, collected in the rete testis, and transported to the epididymis via EDs, where they mature. Mature sperm are stored in the cauda epididymis and released through the vas deferens. (B) Depiction of a cross-section of the ED along the red dashed line in (A). The ED epithelium consists of MCCs and secretory cells.

The development of spermatozoa takes place in the testis. The seminiferous tubules consist of multiple cell types, including spermatogenic cells, Sertoli cells, and peritubular myoid cells. The spermatogenic cycle occurs in waves, and different regions of the seminiferous tubules contain spermatogenic cells at varying steps of differentiation. Sertoli cells are nurse cells that aid spermatogenesis by anchoring developing spermatids to the seminiferous tubule epithelium and establishing the blood-testis barrier [82]. Peritubular myoid cells are smooth muscle-like cells that surround the seminiferous tubules and provide structural rigidity to the seminiferous tubules and contract to push spermatozoa and fluid into the rete testis.

Spermatogenesis is initiated by the asymmetric cell division of spermatogonial stem cells. Following several rounds of mitotic cell divisions, primary spermatocytes go through two rounds of meiosis to give rise to spermatids [75]. Spermatids then undergo spermiogenesis, in which round spermatids transform into elongated spermatozoa with a flagellum and a species-specific head shape [74]. Upon completion of spermiogenesis, the spermatozoa appear morphologically mature but lack motility and the capacity to fertilize an egg [83]. Sertoli cell secretions release spermatozoa into the lumen of the seminiferous tubules and coordinated contractions of peritubular myoid cells propel sperm into the rete testis [79].

Once collected in the rete testis, sperm transit into the EDs. The EDs originate from mesonephric tubules and are critical for concentrating the seminiferous fluid by reabsorbing water and ions and transporting sperm into the epididymis [78,84-86]. Three-dimensional reconstruction of mouse EDs revealed that EDs are $22.5 \mu \mathrm{m}$ in mean radius and $81.9 \mathrm{~mm}$ in length [87]. Sperm transport through the EDs occurs within $45 \mathrm{~min}$ in rats [88]. The number of EDs in the mice varies from 2 to 5 [87,89-91]. In golden Syrian hamsters, there are six ducts [92]. In humans and other large mammals, EDs are more numerous and feed into the epididymis at various sites, whereas EDs in rodents collect into a singular duct (known as the common duct) prior to entering the epididymis [93].

The ED epithelium contains MCCs and nonciliated cells that are surrounded by a single layer of smooth muscle cells (Figure 3B). Several studies have shown that both MCC and nonciliated cell populations in the EDs are required for proper sperm movement into the epididymis $[77,94]$. The abundance of different cell populations varies along the length of the EDs. The proximal end of EDs contains more nonciliated cells than MCCs, whereas the ducts close to the epididymis have substantially more MCCs [95]. Approximately $90 \%$ of the seminiferous fluid is thought to be reabsorbed by the nonciliated cells in the EDs. Absorption of water is driven by aquaporin (AQP) water channels [96,97]. Aside from water, 
nonciliated cells are also responsible for the reabsorption of low molecular weight solutes and proteins $[84,85,98-100]$. These processes are primarily governed by active transport. Passive water transport, on the other hand, is partly regulated by estrogen [94,101]. While estrogen is primarily known for its role in the development and maintenance of the female reproductive system, the estrogen receptors $\alpha$ (ESR1) and $\beta$ (ESR2) are expressed abundantly in the EDs [101-103]. ESR1 regulates expression of sodium/hydrogen exchanger-3 (NHE3 or SLC9A3) and the aquaporins $A Q P 1$ and $A Q P 9$, which modulate sodium and fluid homeostasis within the ED lumen, respectively [94,104,105]. Accordingly, loss of ESR1 in mice leads to defects in fluid reabsorption and ED development $[104,106,107]$. The EDs of $E S R 1^{-/-}$mice were found to be substantially enlarged with low counts of cauda epididymal sperm, due to fluid accumulation [106]. To date, the biological role of ESR2 in the male reproductive tract remains unknown. The smooth muscle cells contract to push sperm toward the epididymis.

The epididymis, which is divided into four regions (initial segment, caput, corpus, and cauda epididymis), serves as the site of sperm concentration, maturation, and storage (Figure 3A) [91]. In the initial segment, fluid absorption continues to occur, albeit to a much lesser degree than in the EDs [100,107]. Throughout the rest of the epididymis, various secretory and absorptive processes set up a unique microenvironment that increases the fertilization competency of the sperm. As such, early studies have reported that mouse sperm isolated from the caput yielded a fertilization rate of only $11 \%$ in vitro, compared to $33 \%$ when cauda epididymal sperm were used [108]. Furthermore, normal development to the blastocyst stage was observed in $48 \%$ of those successfully fertilized with cauda sperm, while only $8 \%$ of caput sperm embryos developed to a blastocyst. After passage through the corpus epididymis, sperm finally reach the cauda epididymis, where they are stored for release via the vas deferens.

\section{Roles of Multiciliated Cells in Efferent Ducts}

As the conduit between the testis and the epididymis, the EDs are essential for male fertility. As spermatozoa leave the testis, they are concentrated 20-fold by passing through the EDs $[98,106]$. The ED is the only portion of the entire male reproductive tract that harbors MCCs. Like typical motile multicilia, ED multicilia have a $9+2$ microtubule organization [77]. However, the tips of ED multicilia show twisting of the axonemal microtubules and are capped with a structure known as the ciliary crown that consists of small claw-like extensions [77]. Ciliary claws are also found in other multiciliated tissues [109] and are approximately $5 \mathrm{~nm}$ in width, although their functional significance is currently unknown. As observed in the airway, oviduct, spinal cord, and brain ventricles, it has been proposed that the sweeping motion of multicilia in the EDs propel sperm from the rete testis to the epididymis. However, recent findings suggest that multicilia in the ED beat in a whip-like rotary motion that stirs the contents of the lumen to prevent sperm aggregation $[77,79]$. Without functional MCCs in EDs, sperm aggregate, ultimately leading to obstruction of the EDs. This may cause fluid retention and back pressure in seminiferous tubules, resulting in degeneration of the seminiferous epithelium and infertility. Ligation of the EDs, which simulates ED obstruction, recapitulated these findings, supporting the idea that loss of multicilia leads to a blockage in the EDs [110,111]. Several mouse models with defective multicilia have been reported to show extensive sperm occlusion in the ED, which prevents sperm transit from the testis to the epididymis, resulting in male infertility (Table 1) [112-115]. 
Table 1. Mouse models and human patients with defective ED multicilia.

\begin{tabular}{|c|c|c|c|c|}
\hline Mouse & Ciliary Function & Male Reproductive Phenotypes & Human & Ref \\
\hline $\begin{array}{l}\text { E2F } 4^{f l / f l} / E 2 F 5^{+/-} \\
\quad \text { Villin-Cre }\end{array}$ & $\begin{array}{l}\text { TFs; early MCC } \\
\text { differentiation }\end{array}$ & $\begin{array}{l}\text { Infertility; Dilation of STs and RT; Sperm } \\
\text { accumulation in EDs; Little to no sperm in CE; } \\
\text { Reduced AQP1 expression in EDs }\end{array}$ & & [113] \\
\hline GEMC1 $^{-/-}$ & $\begin{array}{l}\text { TF; early MCC } \\
\text { differentiation }\end{array}$ & $\begin{array}{c}\text { Infertility; Dilation of STs and RT; SC } \\
\text { degeneration; Sperm accumulation in EDs; } \\
\text { No sperm in CE }\end{array}$ & & [115] \\
\hline$M C I D A S^{-/-}$ & $\begin{array}{l}\text { TF; early MCC } \\
\text { differentiation }\end{array}$ & $\begin{array}{c}\text { Infertility; Dilation of STs and RT; SC } \\
\text { degeneration; Sperm accumulation in EDs; } \\
\text { No sperm in CE }\end{array}$ & $\begin{array}{l}\text { Azoospermia; Loss } \\
\text { of ED multicilia }\end{array}$ & [115] \\
\hline $\mathrm{CCNO}^{-/-}$ & $\begin{array}{l}\text { Cyclin } \mathrm{O} \text {; deuterosome } \\
\text { formation and centriole } \\
\text { amplification }\end{array}$ & $\begin{array}{l}\text { Infertility; Dilation of STs and RT; Sperm } \\
\text { accumulation in EDs; No sperm in CE }\end{array}$ & & [115] \\
\hline $\begin{array}{l}\text { miR- } \\
34 \mathrm{~b} / \mathrm{c}^{-/-} / \mathrm{miR}- \\
449^{-/-}\end{array}$ & $\begin{array}{l}\text { microRNAs; early MCC } \\
\text { differentiation }\end{array}$ & $\begin{array}{l}\text { Infertility; Dilation of STs and RT; Sperm } \\
\text { granuloma in RT; Sperm accumulation in EDs }\end{array}$ & & [79] \\
\hline Mdnah5 $5^{\text {mut } / m u t}$ & $\begin{array}{l}\text { ODA component; ciliary } \\
\text { beating }\end{array}$ & $\begin{array}{l}\text { Reduced sperm counts; Dilation of RT; Sperm } \\
\text { accumulation in EDs; Little to no sperm in CE }\end{array}$ & $\begin{array}{l}\text { Oligozoospermia; } \\
\text { Normal sperm } \\
\text { motility }\end{array}$ & [112] \\
\hline $\begin{array}{c}\text { FOXJ1- } \\
\text { Cre;Cep164 } 4^{f l f l}\end{array}$ & $\begin{array}{l}\text { Distal appendage } \\
\text { component; recruitment of } \\
\text { Cby1/ciBAR complexes }\end{array}$ & $\begin{array}{l}\text { Infertility; Reduced sperm counts; Dilation of } \\
\text { STs and RT; Sperm accumulation in EDs; } \\
\text { Sperm aggregation in STs and CE }\end{array}$ & & [114] \\
\hline
\end{tabular}

\section{Mouse Models with Defective Multicilia in Efferent Ducts}

The E2F family of transcription factors consist of 8 members in mammals (E2F1-8) and regulate the G1/S transition of the cell cycle [116-118]. Among them, E2F4 and E2F5 play key roles in MCC differentiation [38]. During MCC differentiation, GEMC1 and MCIDAS form a complex with E2F4/5 and DP1 transcription factors to induce expression of critical MCC genes, such as CCNO and FOXJ1 [38,40,119]. E2F4 ${ }^{-/-}$mice suffer from chronic rhinitis and associated opportunistic bacterial infections, and more than $85 \%$ of them die by 3 weeks of age [120]. Consistent with these phenotypes, $E 2 F 4^{-/-}$mice show an absence of MCCs from the entire airway epithelium and the epithelium of submucosal glands in the paranasal sinuses. Importantly, expression of FOXJ1 is abolished in the $E 2 F 4^{-/-}$respiratory epithelium, indicating that E2F4 acts upstream of FOXJ1. E2F5 ${ }^{-/-}$ mice develop hydrocephalus around 3-4 weeks after birth, and most die within 6 weeks of age [121]. This suggests that E2F5 is necessary for ependymal MCC differentiation in brain ventricles, although the status of multicilia in $E 2 \mathrm{~F}^{-/-}$mice have not been investigated. E2F4 and E2F5 play overlapping and redundant roles, since simultaneous deletion of E2F4 and E2F5 leads to neonatal lethality [116]. Interestingly, conditional deletion of E2F4 in the EDs in combination with heterozygous mutation of $E 2 F 5\left(E 2 F 4^{f l f l} / E 2 F 5^{+/-}\right.$;Villin-Cre $)$ results in defective MCCs and male infertility [113]. Analysis of the male reproductive tract revealed an accumulation of sperm in the EDs, expansion of the seminiferous tubule lumen, dilation of the rete testis, and little to no sperm in the epididymis. Furthermore, MCCs in the EDs failed to differentiate and form multicilia, and nonciliated cell development was also altered with reduced expression of estrogen receptor- $\alpha$ (ESR1) and aquaporin 1 (AQP1). Collectively, these data clearly demonstrate that E2F4 and E2F5 are important for differentiation of MCCs in the EDs and, hence, male fertility.

GEMC1 and MCIDAS belong to the Geminin family of cell cycle and transcriptional regulators and are essential for MCC differentiation. GEMC1 ${ }^{-/}$mice are significantly smaller than their wild-type counterparts, lack multicilia in the brain ventricle, respiratory system, and reproductive tract, and display common ciliopathy features, such as hydrocephalus and infertility in both sexes [40,44]. Transmission electron microscopy or immunofluorescence staining of the adult tracheal epithelium revealed no identifiable 
MCCs in GEMC1 ${ }^{-/-}$mice. Moreover, transcriptional profiling of the trachea and oviduct of $G E M C 1^{-/-}$mice using microarrays showed reduced expression levels of many ciliary genes, including MCIDAS, FOXJ1, and CCNO [40]. In agreement with this, GEMC1 directly activates the upstream regulatory sequence of MCIDAS and FOXJ1 [40]. Similarly, $M C I D A S^{-1-}$ mice are severely runted and show hydrocephalus and infertility without any detectable multicilia [45]. In contrast to $G E M C 1^{-/-}$mice, MCCs in $M C I D A S^{-1-}$ mice express FOXJ1 and other MCC transcription factors. This suggests that MCIDAS is not required for the specification of the MCC lineage but necessary for subsequent differentiation processes, such as centriole replication. GEMC1 and MCIDAS, as well as their downstream target CCNO, are essential for male fertility in mice [115]. CCNO (cyclin O) plays a key role in centriole amplification during MCC differentiation [122,123]. CCNO expression is restricted to MCCs, and $\mathrm{CCNO}^{-1-}$ mice exhibit characteristic features of MCC dysfunction, including hydrocephalus, mucociliary clearance deficit, and infertility $[123,124]$. $\mathrm{GEMC1}^{-/-}, \mathrm{MCIDAS}^{-/-}$, and $\mathrm{CCNO}^{-/-}$male mice are infertile, due to defective multicilia in the EDs [115]. These mice show similar phenotypes, such as thinning of seminiferous tubule epithelia, dilation of the rete testis, sperm accumulation in the EDs, and lack of sperm in the epididymis. Notably, homozygous frameshift mutations in MCIDAS have been recently reported in an infertile male patient showing no sperm in the ejaculate (azoospermia) with almost complete loss of multicilia in the EDs [125].

Similarly, deletion of the functionally related microRNA clusters $m i R-34 / m i R-449$ in mice yields the common phenotypes associated with defective multicilia, including male infertility. However, single knockout mice are viable and fertile with no apparent phenotypes $[35,79,126-130]$. A spermatogenic cell-specific miR-34/miR-449-double conditional mouse line, generated by mating with a Stra8-Cre driver mouse, shows normal male fertility [79], indicating that spermatogenesis proceeds normally in the absence of $\mathrm{miR}-34 / \mathrm{miR}-449$. Closer analyses of $m i R-34 \mathrm{~b} / \mathrm{c}^{-/-} / \mathrm{miR}-449^{-/-}$male mice revealed loss of multicilia in the EDs, leading to sperm clumping, rete testis dilation, and ED occlusion [79]. MCC-specific inactivation of miR-34/miR-449 using a FOXJ1-Cre driver phenocopies the ED deficits of the germline $m i R-34 b / c^{-1-} / m i R-449^{-1-}$ male mice, reinforcing the view that loss of multicilia in the EDs is the primary cause of their male infertility. Yuan et al. also reported that multicilia in the EDs uniquely show whip-like beating with constant changes in direction and generate turbulence to maintain immotile sperm in suspension, which are further pushed into the epididymis by the peristaltic contractions of the ED smooth muscle [79].

Dynein axonemal heavy chain 5 (DNAH5) is a component of the outer dynein arm of multicilia and essential for ciliary beating. Mutations in DNAH5 represent the most frequent cause of PCD and account for 15-2\% of PCD cases [131]. A recent study reported that mice deficient for DNAH5 (Mdnah5 $5^{\text {mut } / m u t}$ ) exhibit accumulation of sperm in the EDs, rete testis dilation, and infertility, due to dysmotility of ED multicilia that lack the outer dynein arms [112]. In contrast, sperm isolated from Mdnah $5^{m u t / m u t}$ mice show normal flagellar ultrastructures and motility. Consistent with these findings, DNAH5 is only detectable along multicilia but not in sperm flagella. Notably, similar to the phenotypes of Mdnah5 $5^{m u t / m u t}$ mice, human PCD patients with loss-of-function mutations in DNAH5 manifest decreased sperm counts (oligozoospermia) and dilation of the epididymal head but have normal sperm motility. Thus, this study clearly establishes that loss of motility of multicilia in the EDs is sufficient to cause ED obstruction and male infertility.

CEP164 is a distal appendage protein that is essential for ciliogenesis (Figure 2) $[64,132$, 133]. CEP164 recruits small vesicles to basal bodies to facilitate anchoring of basal bodies to the apical cell surface, thereby promoting cilium assembly $[12,64]$. Our group conditionally eliminated CEP164 in MCCs using a FOXJ1-Cre mouse line (FOXJ1-Cre;CEP164 $\left.f^{f l f l}\right)$. FOXJ1$\mathrm{Cre} ; \mathrm{Cep} 164^{\mathrm{fl} / \mathrm{fl}}$ mice show a profound loss of airway, ependymal, and oviduct multicilia and develop hydrocephalus and male infertility. About $20 \%$ die around weaning age with severe hydrocephalus. Basal body recruitment of CEP164 interactors Cby1 and ciBAR1, and ciBAR2 was severely reduced in primary cultures of tracheal MCCs in the absence of 
CEP164. More recently, we have demonstrated that their male infertility is attributable to an almost complete loss of multicilia in the EDs (Figure 4) [114]. FOXJ1-Cre;Cep164 fl/fl mice displayed extensive dilation of the rete testis and aggregation of sperm in EDs (Figure 4), along with aggregation of sperm in the seminiferous tubules. The sperm aggregation in the seminiferous tubules has not been reported in other mouse models with impaired MCCs, suggesting that the ED defects in FOXJ1-Cre;CEP164 ${ }^{f l / f l}$ mice are more severe or that CEP164 plays a role in biological processes distinct from MCC differentiation. Loss of CEP164 also resulted in basal body docking defects, as evidenced by accumulation of basal bodies in the cytoplasm of the ED epithelium. These studies further support the notion that dysfunctional multicilia in the EDs can be a cause of male infertility, independent of sperm flagellar formation. The role of CEP164 in spermatogenesis remains to be explored. Mutations in CEP164 have been identified in a host of ciliopathy patients including nephronophthisis, BBS, PCD, and oral-facial-digital syndrome [134-138], but male reproductive phenotypes have not been reported.

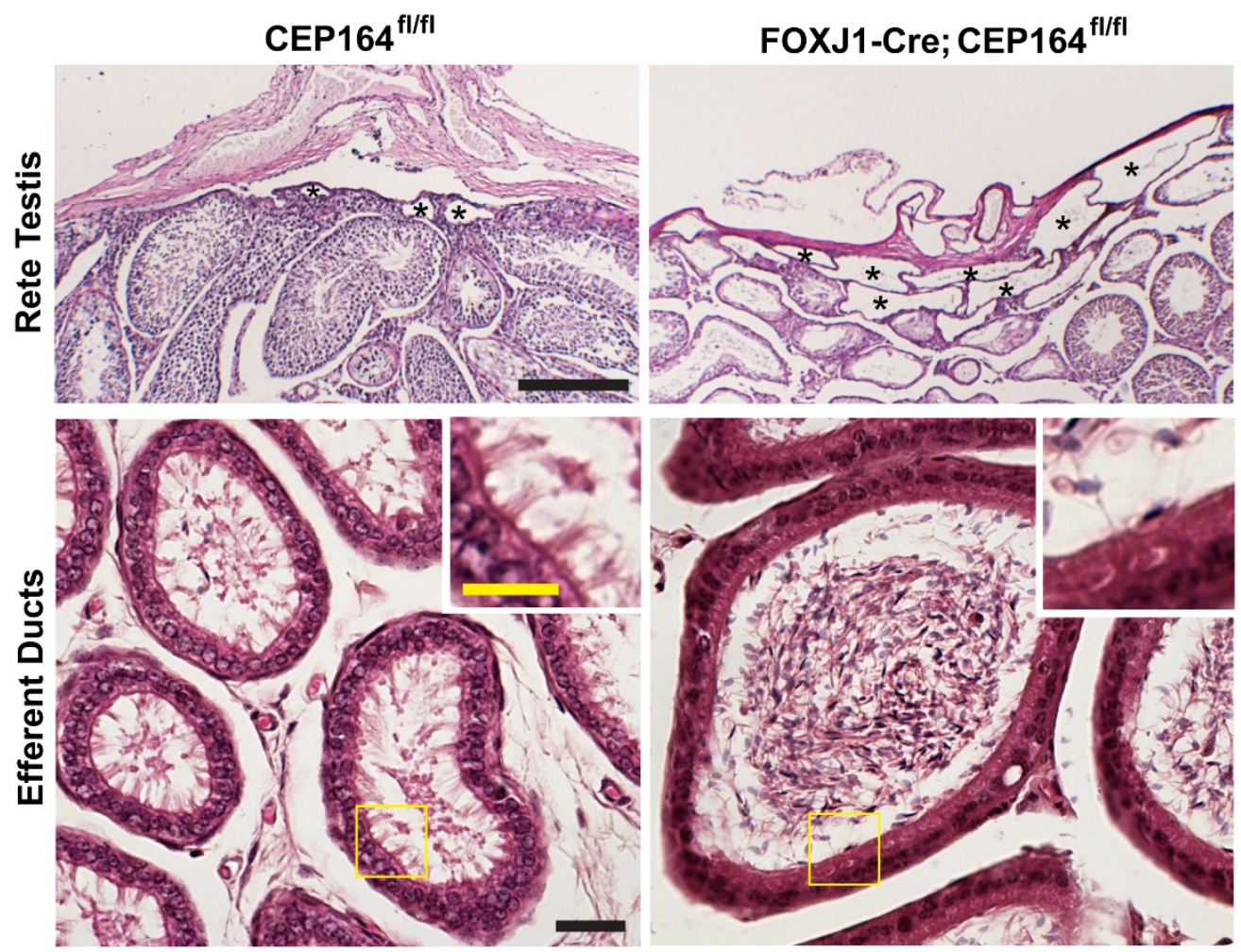

Figure 4. Rete testis dilation and sperm aggregation in the EDs of the FOXJ1-Cre;Cep164 flffl mouse model. PAS staining of the rete testis (top) and H\&E staining of EDs (bottom) from adult mice. Asterisks indicate the tubules of the rete testis. Scale bar, $200 \mu \mathrm{m}$. The boxed areas in yellow are magnified in the insets to show multicilia. Note the lack of multicilia in the EDs of FOXJ1Cre;Cep164 $4^{f l f l}$ mice. Scale bars, $20 \mu \mathrm{m}$ and $10 \mu \mathrm{m}$ (magnified images).

\section{Conclusions}

MCCs in the EDs play an essential role in male fertility by mediating the swift transport of sperm from the testis into the epididymis. While the differentiation mechanisms and key roles of MCCs in the respiratory, ependymal, and oviduct epithelia have been extensively studied, the important function of MCCs in the EDs has only recently been recognized. Data from mouse models and human patients as described above provide compelling evidence that multicilia in the EDs play essential roles in male fertility. Impaired MCC functions in EDs present with sperm aggregation, obstruction of sperm transport, and degeneration of germ cells in the testis, ultimately leading to infertility. Although more 
genetic studies of infertile men are required, multicilia in the EDs may be considered as a critical factor when diagnosing male infertility.

Author Contributions: Conceptualization, M.H., K.-I.T.; writing—original draft preparation, review, and editing, M.H., K.-I.T., E.N.K., D.C., F.-Q.L.; funding acquisition, K.-I.T., F.-Q.L. All authors have read and agreed to the published version of the manuscript.

Funding: Work in the laboratory of K.I.T. was supported by grants from the National Heart, Lung, and Blood Institute (R01HL139643) and the National Institute of Diabetes and Digestive and Kidney Disease (R01DK123641).

Institutional Review Board Statement: All mice were handled in accordance with NIH guidelines, and all protocols were approved by the Institutional Animal Care and Use Committee (IACUC) of Stony Brook University (\#245427).

Informed Consent Statement: Not applicable.

Data Availability Statement: Not applicable.

Conflicts of Interest: The authors declare no conflict of interest.

\section{References}

1. Anvarian, Z.; Mykytyn, K.; Mukhopadhyay, S.; Pedersen, L.B.; Christensen, S.T. Cellular signalling by primary cilia in development, organ function and disease. Nat. Rev. Nephrol. 2019, 15, 199-219. [CrossRef] [PubMed]

2. Goetz, S.C.; Anderson, K.V. The primary cilium: A signalling centre during vertebrate development. Nat. Rev. Genet. 2010, 11, 331-344. [CrossRef]

3. Hildebrandt, F.; Benzing, T.; Katsanis, N. Ciliopathies. N. Engl. J. Med. 2011, 364, 1533-1543. [CrossRef]

4. Hamada, H. Molecular and cellular basis of left-right asymmetry in vertebrates. Proc. Jpn. Acad. Ser. B Phys. Biol. Sci. 2020, 96, 273-296. [CrossRef]

5. Shinohara, K.; Hamada, H. Cilia in Left-Right Symmetry Breaking. Cold Spring Harb. Perspect. Biol. 2017, 9, a028282. [CrossRef] [PubMed]

6. Garcia, G.; Raleigh, D.R.; Reiter, J.F. How the Ciliary Membrane Is Organized Inside-Out to Communicate Outside-In. Curr. Biol. 2018, 28, R421-R434. [CrossRef]

7. Conduit, S.E.; Vanhaesebroeck, B. Phosphoinositide lipids in primary cilia biology. Biochem. J. 2020, 477, 3541-3565. [CrossRef]

8. Li, S.; Winuthayanon, W. Oviduct: Roles in fertilization and early embryo development. J. Endocrinol. 2017, 232, R1-R26. [CrossRef] [PubMed]

9. Kumar, V.; Umair, Z.; Kumar, S.; Goutam, R.S.; Park, S.; Kim, J. The regulatory roles of motile cilia in CSF circulation and hydrocephalus. Fluids Barriers CNS 2021, 18, 31. [CrossRef]

10. Inaba, K.; Mizuno, K. Sperm dysfunction and ciliopathy. Reprod. Med. Biol. 2016, 15, 77-94. [CrossRef] [PubMed]

11. Sironen, A.; Shoemark, A.; Patel, M.; Loebinger, M.R.; Mitchison, H.M. Sperm defects in primary ciliary dyskinesia and related causes of male infertility. Cell Mol. Life Sci. 2020, 77, 2029-2048. [CrossRef]

12. Schmidt, K.N.; Kuhns, S.; Neuner, A.; Hub, B.; Zentgraf, H.; Pereira, G. Cep164 mediates vesicular docking to the mother centriole during early steps of ciliogenesis. J. Cell Biol. 2012, 199, 1083-1101. [CrossRef] [PubMed]

13. Burke, M.C.; Li, F.-Q.; Cyge, B.; Arashiro, T.; Brechbuhl, H.M.; Chen, X.; Siller, S.S.; Weiss, M.A.; O'Connell, C.B.; Love, D.; et al. Chibby promotes ciliary vesicle formation and basal body docking during airway cell differentiation. J. Cell Biol. 2014, 207, 123-137. [CrossRef]

14. Wei, Q.; Ling, K.; Hu, J. The essential roles of transition fibers in the context of cilia. Curr. Opin. Cell Biol. 2015, 35, 98-105. [CrossRef] [PubMed]

15. Reiter, J.F.; Blacque, O.E.; Leroux, M.R. The base of the cilium: Roles for transition fibres and the transition zone in ciliary formation, maintenance and compartmentalization. EMBO Rep. 2012, 13, 608-618. [CrossRef] [PubMed]

16. Hsiao, Y.-C.; Tuz, K.; Ferland, R.J. Trafficking in and to the primary cilium. Cilia 2012, 1, 4. [CrossRef]

17. Emmer, B.T.; Maric, D.; Engman, D.M. Molecular mechanisms of protein and lipid targeting to ciliary membranes. J. Cell Sci. 2010, 123, 529-536. [CrossRef]

18. Rosenbaum, J.L.; Witman, G.B. Intraflagellar transport. Nat. Rev. Mol. Cell Biol. 2002, 3, 813-825. [CrossRef]

19. Ishikawa, H.; Marshall, W.F. Intraflagellar Transport and Ciliary Dynamics. Cold Spring Harb. Perspect. Biol. 2017, 9, a021998. [CrossRef] [PubMed]

20. Vladar, E.K.; Stearns, T. Molecular characterization of centriole assembly in ciliated epithelial cells. J. Cell Biol. 2007, 178, 31-42. [CrossRef]

21. Dawe, H.R.; Farr, H.; Gull, K. Centriole/basal body morphogenesis and migration during ciliogenesis in animal cells. J. Cell Sci. 2007, 120, 7-15. [CrossRef]

22. Nigg, E.A.; Raff, J.W. Centrioles, centrosomes, and cilia in health and disease. Cell 2009, 139, 663-678. [CrossRef] 
23. Pazour, G.J.; Quarmby, L.; Smith, A.O.; Desai, P.B.; Schmidts, M. Cilia in cystic kidney and other diseases. Cell Signal. 2020, 69, 109519. [CrossRef]

24. Ma, M.; Gallagher, A.-R.; Somlo, S. Ciliary Mechanisms of Cyst Formation in Polycystic Kidney Disease. Cold Spring Harb. Perspect. Biol. 2017, 9, a028209. [CrossRef]

25. Leigh, M.W.; Pittman, J.E.; Carson, J.L.; Ferkol, T.W.; Dell, S.D.; Davis, S.D.; Knowles, M.R.; Zariwala, M.A. Clinical and genetic aspects of primary ciliary dyskinesia/Kartagener syndrome. Genet. Med. 2009, 11, 473-487. [CrossRef]

26. Horani, A.; Ferkol, T.W.; Dutcher, S.K.; Brody, S.L. Genetics and biology of primary ciliary dyskinesia. Paediatr. Respir. Rev. 2016, 18, 18-24. [CrossRef] [PubMed]

27. Legendre, M.; Zaragosi, L.-E.; Mitchison, H.M. Motile cilia and airway disease. Semin. Cell Dev. Biol. 2021, 110, 19-33. [CrossRef] [PubMed]

28. Lee, L.; Ostrowski, L.E. Motile cilia genetics and cell biology: Big results from little mice. Cell Mol. Life Sci. 2021, 78, 769-797. [CrossRef] [PubMed]

29. Wallmeier, J.; Nielsen, K.G.; Kuehni, C.E.; Lucas, J.S.; Leigh, M.W.; Zariwala, M.A.; Omran, H. Motile ciliopathies. Nat. Rev. Dis. Primers 2020, 6, 77. [CrossRef]

30. Cibois, M.; Luxardi, G.; Chevalier, B.; Thomé, V.; Mercey, O.; Zaragosi, L.-E.; Barbry, P.; Pasini, A.; Marcet, B.; Kodjabachian, L. BMP signalling controls the construction of vertebrate mucociliary epithelia. Development 2015, 142, 2352-2363. [CrossRef]

31. Guseh, J.S.; Bores, S.A.; Stanger, B.Z.; Zhou, Q.; Anderson, W.J.; Melton, D.A.; Rajagopal, J. Notch signaling promotes airway mucous metaplasia and inhibits alveolar development. Development 2009, 136, 1751-1759. [CrossRef]

32. Tsao, P.-N.; Vasconcelos, M.; Izvolsky, K.I.; Qian, J.; Lu, J.; Cardoso, W.V. Notch signaling controls the balance of ciliated and secretory cell fates in developing airways. Development 2009, 136, 2297-2307. [CrossRef]

33. Nishimura, Y.; Hamazaki, T.S.; Komazaki, S.; Kamimura, S.; Okochi, H.; Asashima, M. Ciliated cells differentiated from mouse embryonic stem cells. Stem Cells 2006, 24, 1381-1388. [CrossRef]

34. Chevalier, B.; Adamiok, A.; Mercey, O.; Revinski, D.R.; Zaragosi, L.-E.; Pasini, A.; Kodjabachian, L.; Barbry, P.; Marcet, B miR-34/449 control apical actin network formation during multiciliogenesis through small GTPase pathways. Nat. Commun. 2015, 6, 8386. [CrossRef]

35. Wu, J.; Bao, J.; Kim, M.; Yuan, S.; Tang, C.; Zheng, H.; Mastick, G.S.; Xu, C.; Yan, W. Two miRNA clusters, miR-34b/c and miR-449, are essential for normal brain development, motile ciliogenesis, and spermatogenesis. Proc. Natl. Acad. Sci. USA 2014, 111, E2851-E2857. [CrossRef] [PubMed]

36. Marcet, B.; Chevalier, B.; Coraux, C.; Kodjabachian, L.; Barbry, P. MicroRNA-based silencing of Delta/Notch signaling promotes multiple cilia formation. Cell Cycle 2011, 10, 2858-2864. [CrossRef] [PubMed]

37. Marcet, B.; Chevalier, B.; Luxardi, G.; Coraux, C.; Zaragosi, L.-E.; Cibois, M.; Robbe-Sermesant, K.; Jolly, T.; Cardinaud, B.; Moreilhon, C.; et al. Control of vertebrate multiciliogenesis by miR-449 through direct repression of the Delta/Notch pathway. Nat. Cell Biol. 2011, 13, 693-699. [CrossRef]

38. Ma, L.; Quigley, I.; Omran, H.; Kintner, C. Multicilin drives centriole biogenesis via E2f proteins. Genes Dev. 2014, $28,1461-1471$. [CrossRef] [PubMed]

39. Stubbs, J.L.; Vladar, E.K.; Axelrod, J.D.; Kintner, C. Multicilin promotes centriole assembly and ciliogenesis during multiciliate cell differentiation. Nat. Cell Biol. 2012, 14, 140-147. [CrossRef] [PubMed]

40. Arbi, M.; Pefani, D.E.; Kyrousi, C.; Lalioti, M.E.; Kalogeropoulou, A.; Papanastasiou, A.D.; Taraviras, S.; Lygerou, Z. GemC1 controls multiciliogenesis in the airway epithelium. EMBO Rep. 2016, 17, 400-413. [CrossRef]

41. Arbi, M.; Pefani, D.-E.; Taraviras, S.; Lygerou, Z. Controlling centriole numbers: Geminin family members as master regulators of centriole amplification and multiciliogenesis. Chromosoma 2018, 127, 151-174. [CrossRef]

42. Zhou, F.; Narasimhan, V.; Shboul, M.; Chong, Y.L.; Reversade, B.; Roy, S. Gmnc is a master regulator of the multiciliated cell differentiation program. Curr. Biol. 2015, 25, 3267-3273. [CrossRef] [PubMed]

43. Kyrousi, C.; Arbi, M.; Pilz, G.A.; Pefani, D.E.; Lalioti, M.E.; Ninkovic, J.; Gotz, M.; Lygerou, Z.; Taraviras, S. Mcidas and GemC1 are key regulators for the generation of multiciliated ependymal cells in the adult neurogenic niche. Development 2015, 142, 3661-3674. [CrossRef] [PubMed]

44. Terré, B.; Piergiovanni, G.; Segura-Bayona, S.; Gil-Gómez, G.; Youssef, S.A.; Attolini, C.S.-O.; Wilsch-Bräuninger, M.; Jung, C.; Rojas, A.; Marjanović, M.; et al. GEMC 1 is a critical regulator of multiciliated cell differentiation. EMBO J. 2016, 35, 942-960. [CrossRef] [PubMed]

45. Lu, H.; Anujan, P.; Zhou, F.; Zhang, Y.; Chong, Y.L.; Bingle, C.D.; Roy, S. Mcidas mutant mice reveal a two-step process for the specification and differentiation of multiciliated cells in mammals. Development 2019, 146, dev172643. [CrossRef]

46. Vladar, E.K.; Mitchell, B.J. It's a family act: The geminin triplets take center stage in motile ciliogenesis. EMBO J. 2016, 35, 904-906. [CrossRef]

47. Kim, S.; Ma, L.; Shokhirev, M.N.; Quigley, I.; Kintner, C. Multicilin and activated E2f4 induce multiciliated cell differentiation in primary fibroblasts. Sci. Rep. 2018, 8, 12369. [CrossRef]

48. Zhao, H.; Zhu, L.; Zhu, Y.; Cao, J.; Li, S.; Huang, Q.; Xu, T.; Huang, X.; Yan, X.; Zhu, X. The Cep63 paralogue Deup1 enables massive de novo centriole biogenesis for vertebrate multiciliogenesis. Nat. Cell Biol. 2013, 15, 1434-1444. [CrossRef]

49. Marshall, C.B.; Mays, D.J.; Beeler, J.S.; Rosenbluth, J.M.; Boyd, K.L.; Guasch, G.L.S.; Shaver, T.M.; Tang, L.J.; Liu, Q.; Shyr, Y.; et al. P73 Is Required for Multiciliogenesis and Regulates the Foxj1-Associated Gene Network. Cell Rep. 2016, 14, 2289-2300. [CrossRef] 
50. Nemajerova, A.; Kramer, D.; Siller, S.S.; Herr, C.; Shomroni, O.; Pena, T.; Suazo, C.G.; Glaser, K.; Wildung, M.; Steffen, H.; et al. TAp73 is a central transcriptional regulator of airway multiciliogenesis. Genes Dev. 2016, 30, 1300-1312. [CrossRef]

51. Spassky, N.; Meunier, A. The development and functions of multiciliated epithelia. Nat. Rev. Mol. Cell Biol. 2017, 18, 423-436. [CrossRef] [PubMed]

52. Breslow, D.K.; Holland, A.J. Mechanism and Regulation of Centriole and Cilium Biogenesis. Annu. Rev. Biochem. 2019, 88, 691-724. [CrossRef] [PubMed]

53. Sorokin, S.P. Reconstructions of centriole formation and ciliogenesis in mammalian lungs. J. Cell Sci. 1968, 3, 207-230. [CrossRef]

54. Dehring, D.A.K.; Vladar, E.K.; Werner, M.E.; Mitchell, J.W.; Hwang, P.; Mitchell, B.J. Deuterosome-mediated centriole biogenesis. Dev. Cell 2013, 27, 103-112. [CrossRef]

55. Al Jord, A.; Lemaître, A.-I.; Delgehyr, N.; Faucourt, M.; Spassky, N.; Meunier, A. Centriole amplification by mother and daughter centrioles differs in multiciliated cells. Nature 2014, 516, 104-107. [CrossRef]

56. Zhao, H.; Chen, Q.; Fang, C.; Huang, Q.; Zhou, J.; Yan, X.; Zhu, X. Parental centrioles are dispensable for deuterosome formation and function during basal body amplification. EMBO Rep. 2019, 20, e46735. [CrossRef]

57. Nanjundappa, R.; Kong, D.; Shim, K.; Stearns, T.; Brody, S.L.; Loncarek, J.; Mahjoub, M.R. Regulation of cilia abundance in multiciliated cells. eLife 2019, 8, e44039. [CrossRef]

58. Mercey, O.; Levine, M.S.; LoMastro, G.M.; Rostaing, P.; Brotslaw, E.; Gomez, V.; Kumar, A.; Spassky, N.; Mitchell, B.J.; Meunier, A.; et al. Massive centriole production can occur in the absence of deuterosomes in multiciliated cells. Nat. Cell Biol. 2019, 21, 1544-1552. [CrossRef] [PubMed]

59. Li, F.-Q.; Siller, S.S.; Takemaru, K.-I. Basal body docking in airway ciliated cells. Oncotarget 2015, 6, 19944-19945. [CrossRef]

60. Lü, Q.; Insinna, C.; Ott, C.; Stauffer, J.; Pintado, P.A.R.; Rahajeng, J.; Baxa, U.; Walia, V.; Cuenca, A.; Hwang, Y.-S.; et al. Early steps in primary cilium assembly require EHD1/EHD3-dependent ciliary vesicle formation. Nat. Cell Biol. 2015, 17, 228-240. [CrossRef]

61. Feng, S.; Knödler, A.; Ren, J.; Zhang, J.; Zhang, X.; Hong, Y.; Huang, S.; Peränen, J.; Guo, W. A Rab8 Guanine Nucleotide Exchange Factor-Effector Interaction Network Regulates Primary Ciliogenesis. J. Biol. Chem. 2012, 287, 15602-15609. [CrossRef] [PubMed]

62. Westlake, C.J.; Baye, L.M.; Nachury, M.V.; Wright, K.J.; Ervin, K.E.; Phu, L.; Chalouni, C.; Beck, J.S.; Kirkpatrick, D.S.; Slusarski, D.C.; et al. Primary cilia membrane assembly is initiated by Rab11 and transport protein particle II (TRAPPII) complex-dependent trafficking of Rabin8 to the centrosome. Proc. Natl. Acad. Sci. USA 2011, 108, 2759-2764. [CrossRef]

63. Voronina, V.A.; Takemaru, K.-I.; Treuting, P.; Love, D.; Grubb, B.R.; Hajjar, A.M.; Adams, A.; Li, F.-Q.; Moon, R.T. Inactivation of Chibby affects function of motile airway cilia. J. Cell Biol. 2009, 185, 225-233. [CrossRef]

64. Siller, S.S.; Sharma, H.; Li, S.; Yang, J.; Zhang, Y.; Holtzman, M.J.; Winuthayanon, W.; Colognato, H.; Holdener, B.C.; Li, F.-Q.; et al. Conditional knockout mice for the distal appendage protein CEP164 reveal its essential roles in airway multiciliated cell differentiation. PLoS Genet. 2017, 13, e1007128. [CrossRef]

65. Li, F.-Q.; Chen, X.; Fisher, C.; Siller, S.S.; Zelikman, K.; Kuriyama, R.; Takemaru, K.-I. BAR Domain-Containing FAM92 Proteins Interact with Chibby1 To Facilitate Ciliogenesis. Mol. Cell. Biol. 2016, 36, 2668-2680. [CrossRef] [PubMed]

66. Meunier, A.; Azimzadeh, J. Multiciliated Cells in Animals. Cold Spring Harb. Perspect. Biol. 2016, 8, a028233. [CrossRef] [PubMed]

67. Werner, M.E.; Hwang, P.; Huisman, F.; Taborek, P.; Yu, C.C.; Mitchell, B.J. Actin and microtubules drive differential aspects of planar cell polarity in multiciliated cells. J. Cell Biol. 2011, 195, 19-26. [CrossRef]

68. Vladar, E.K.; Königshoff, M. Noncanonical Wnt planar cell polarity signaling in lung development and disease. Biochem. Soc. Trans. 2020, 48, 231-243. [CrossRef] [PubMed]

69. Ohata, S.; Alvarez-Buylla, A. Planar Organization of Multiciliated Ependymal (E1) Cells in the Brain Ventricular Epithelium Trends Neurosci. 2016, 39, 543-551. [CrossRef] [PubMed]

70. Gegg, M.; Böttcher, A.; Burtscher, I.; Hasenoeder, S.; Van Campenhout, C.; Aichler, M.; Walch, A.; Grant, S.G.; Lickert, H. Flattop regulates basal body docking and positioning in mono- and multiciliated cells. eLife 2014, 3, e03842. [CrossRef]

71. Park, T.J.; Mitchell, B.J.; Abitua, P.B.; Kintner, C.; Wallingford, J.B. Dishevelled controls apical docking and planar polarization of basal bodies in ciliated epithelial cells. Nat. Genet. 2008, 40, 871-879. [CrossRef]

72. Lechtreck, K.F.; Van De Weghe, J.C.; Harris, J.A.; Liu, P. Protein transport in growing and steady-state cilia. Traffic 2017, 18, 277-286. [CrossRef]

73. Werner, S.; Pimenta-Marques, A.; Bettencourt-Dias, M. Maintaining centrosomes and cilia. J. Cell Sci. 2017, 130, 3789-3800. [CrossRef]

74. De Kretser, D.M.; Loveland, K.L.; Meinhardt, A.; Simorangkir, D.; Wreford, N. Spermatogenesis. Hum. Reprod. 1998, 13, 1-8. [CrossRef]

75. Griswold, M.D. Spermatogenesis: The Commitment to Meiosis. Physiol. Rev. 2016, 96, 1-17. [CrossRef] [PubMed]

76. Russell, L.D.; Ettlin, R.A.; Hikim, A.P.S.; Clegg, E.D. Histological and Histopathological Evaluation of the Testis. Int. J. Androl. 1993, 16, 83. [CrossRef]

77. Hess, R.A. Small tubules, surprising discoveries: From efferent ductules in the turkey to the discovery that estrogen receptor alpha is essential for fertility in the male. Anim. Reprod. 2015, 12, 7-23.

78. Hess, R.A. Efferent Ductules: Structure and Function. In Encyclopedia of Reproduction, 2nd ed.; Skinner, M.K., Ed.; Academic Press: Oxford, UK, 2018; pp. 270-278. 
79. Yuan, S.; Liu, Y.; Peng, H.; Tang, C.; Hennig, G.W.; Wang, Z.; Wang, L.; Yu, T.; Klukovich, R.; Zhang, Y.; et al. Motile cilia of the male reproductive system require miR-34/miR-449 for development and function to generate luminal turbulence. Proc. Natl. Acad. Sci. USA 2019, 116, 3584-3593. [CrossRef] [PubMed]

80. Bork, K.; Chevrier, C.; Paquignon, M.; Jouannet, P.; Dacheux, J. Flagellar motility and movement of boar spermatozoa during epididymal transit. Reprod. Nutr. Dev. 1988, 28, 1307-1315. [CrossRef] [PubMed]

81. Dacheux, J.-L.; Dacheux, F. New insights into epididymal function in relation to sperm maturation. Reproduction 2014, 147, R27-R42. [CrossRef] [PubMed]

82. Griswold, M.D. The central role of Sertoli cells in spermatogenesis. Semin. Cell Dev. Biol. 1998, 9, 411-416. [CrossRef]

83. Lacham-Kaplan, O.; Trounson, A. The effects of the sperm motility activators 2-deoxyadenosine and pentoxifylline used for sperm micro-injection on mouse and human embryo development. Hum. Reprod. 1993, 8, 945-952. [CrossRef]

84. Clulow, J.; Jones, R.; Hansen, L.; Man, S. Fluid and electrolyte reabsorption in the ductuli efferentes testis. J. Reprod. Fertil. Suppl. 1998, 53, 1-14. [PubMed]

85. Clulow, J.; Jones, R.C.; Hansen, L.A. Micropuncture and cannulation studies of fluid composition and transport in the ductuli efferentes testis of the rat: Comparisons with the homologous metanephric proximal tubule. Exp. Physiol. 1994, 79, 915-928. [CrossRef] [PubMed]

86. Veeramachaneni, D.N.; Amann, R.P.; Palmer, J.S.; Hinton, B.T. Proteins in luminal fluid of the ram excurrent ducts: Changes in composition and evidence for differential endocytosis. J. Androl. 1990, 11, 140-154. [PubMed]

87. Lambot, M.-A.H.; Mendive, F.; Laurent, P.; Van Schoore, G.; Noël, J.-C.; Vanderhaeghen, P.; Vassart, G. Three-dimensional reconstruction of efferent ducts in wild-type and Lgr4 knock-out mice. Anat. Rec. 2009, 292, 595-603. [CrossRef]

88. English, H.F.; Dym, M. The time required for materials injected into the rete testis to reach points in the caput epididymis of the rat and observations on the absorption of cationic ferritin. Ann. N. Y. Acad. Sci. 1982, 383, 445-446. [CrossRef]

89. Benoit, J. Recherches anatomiques, cytologiques et histophysiologiques, sur les voies excrétices du testicules chez les mammiferes. Archs. Anat. Histol. Embryol. 1926, 5, 173-412.

90. Cunningham, J. On ligature of the vas deferens in the cat and researches on the efferent ducts of the testis in cat, rat and mouse. J. Exp. Biol. 1928, 6, 12-25. [CrossRef]

91. Barack, B.M. Transport of spermatozoa from seminiferous tubules to epididymis in the mouse: A histological and quantitative study. J. Reprod. Fertil. 1968, 16, 35-48. [CrossRef] [PubMed]

92. Ford, J., Jr.; Carnes, K.; Hess, R.A. Ductuli efferentes of the male Golden Syrian hamster reproductive tract. Andrology 2014, 2, 510-520. [CrossRef]

93. Hemeida, N.A.; Sack, W.O.; McEntee, K. Ductuli efferentes in the epididymis of boar, goat, ram, bull, and stallion. Am. J. Vet. Res. 1978, 39, 1892-1900.

94. Zhou, Q.; Clarke, L.; Nie, R.; Carnes, K.; Lai, L.-W.; Lien, Y.-H.H.; Verkman, A.; Lubahn, D.; Fisher, J.S.; Katzenellenbogen, B.S.; et al. Estrogen action and male fertility: Roles of the sodium/hydrogen exchanger-3 and fluid reabsorption in reproductive tract function. Proc. Natl. Acad. Sci. USA 2001, 98, 14132-14137. [CrossRef] [PubMed]

95. Ilio, K.Y.; Hess, R.A. Structure and function of the ductuli efferentes: A review. Microsc. Res. Tech. 1994, 29, 432-467. [CrossRef] [PubMed]

96. Oliveira, C.A.; Carnes, K.; França, L.R.; Hermo, L.; Hess, R.A. Aquaporin-1 and -9 are differentially regulated by oestrogen in the efferent ductule epithelium and initial segment of the epididymis. Biol. Cell 2005, 97, 385-395. [CrossRef] [PubMed]

97. Ruz, R.; Gregory, M.; Smith, C.E.; Cyr, D.G.; Lubahn, D.B.; Hess, R.A.; Hermo, L. Expression of aquaporins in the efferent ductules, sperm counts, and sperm motility in estrogen receptor-alpha deficient mice fed lab chow versus casein. Mol. Reprod. Dev. 2006, 73, 226-237. [CrossRef] [PubMed]

98. Hansen, L.A.; Dacheux, F.; Man, S.Y.; Clulow, J.; Jones, R.C. Fluid reabsorption by the ductuli efferentes testis of the rat is dependent on both sodium and chlorine. Biol. Reprod. 2004, 71, 410-416. [CrossRef]

99. Hermo, L.; Clermont, Y.; Morales, C. Fluid-phase and adsorptive endocytosis in ciliated epithelial cells of the rat ductuli efferentes. Anat. Rec. 1985, 211, 285-294. [CrossRef]

100. Igdoura, S.A.; Hermo, L.; Rosenthal, A.; Morales, C.R. Nonciliated cells of the rat efferent ducts endocytose testicular sulfated glycoprotein-1 (SGP-1) and synthesize SGP-1 derived saposins. Anat. Rec. 1993, 235, 411-424. [CrossRef] [PubMed]

101. Hess, R.A.; Fernandes, S.A.; Gomes, G.R.; Oliveira, C.A.; Lazari, M.F.; Porto, C.S. Estrogen and its receptors in efferent ductules and epididymis. J. Androl. 2011, 32, 600-613. [CrossRef]

102. Nie, R.; Zhou, Q.; Jassim, E.; Saunders, P.T.; Hess, R.A. Differential expression of estrogen receptors alpha and beta in the reproductive tracts of adult male dogs and cats. Biol. Reprod. 2002, 66, 1161-1168. [CrossRef]

103. Zhou, Q.; Nie, R.; Prins, G.S.; Saunders, P.T.; Katzenellenbogen, B.S.; Hess, R.A. Localization of androgen and estrogen receptors in adult male mouse reproductive tract. J. Androl. 2002, 23, 870-881.

104. Joseph, A.; Shur, B.D.; Hess, R.A. Estrogen, efferent ductules, and the epididymis. Biol. Reprod. 2011, 84, 207-217. [CrossRef] [PubMed]

105. Pastor-Soler, N.M.; Fisher, J.S.; Sharpe, R.; Hill, E.; Van Hoek, A.; Brown, D.; Breton, S. Aquaporin 9 expression in the developing rat epididymis is modulated by steroid hormones. Reproduction 2010, 139, 613-621. [CrossRef] [PubMed]

106. Hess, R.A.; Bunick, D.; Lee, K.-H.; Bahr, J.; Taylor, J.A.; Korach, K.S.; Lubahn, D.B. A role for oestrogens in the male reproductive system. Nature 1997, 390, 509-512. [CrossRef] 
107. Hess, R.A.; Zhou, Q.; Nie, R.; Oliveira, C.; Cho, H.; Nakaia, M.; Carnes, K. Estrogens and epididymal function. Reprod. Fertil. Dev. 2001, 13, 273-283. [CrossRef]

108. Wazzan, W.C.; Gwatkin, R.B.; Thomas, A.J., Jr. Zona drilling enhances fertilization by mouse caput epididymal sperm. Mol. Reprod Dev. 1990, 27, 332-336. [CrossRef]

109. Kubo, A.; Yuba-Kubo, A.; Tsukita, S.; Tsukita, S.; Amagai, M. Sentan: A novel specific component of the apical structure of vertebrate motile cilia. Mol. Biol. Cell 2008, 19, 5338-5346. [CrossRef]

110. Soler, C.; Blazquez, C.; Pertusa, J.; Nunez, M.; Nunez, J.; Nunez, A. A comparison of the effects of bilateral efferent duct ligation and of partial epididymectomy on the testes of rats. Reprod. Fertil. Dev. 1990, 2, 321-326. [CrossRef] [PubMed]

111. Nicander, L.; Osman, D.I.; Pløen, L.; Bugge, H.P.; Kvisgaard, K.N. Early effects of efferent ductule ligation on the proximal segment of the rat epididymis. Int. J. Androl. 1983, 6, 91-102. [CrossRef] [PubMed]

112. Aprea, I.; Nöthe-Menchen, T.; Dougherty, G.W.; Raidt, J.; Loges, N.T.; Kaiser, T.; Wallmeier, J.; Olbrich, H.; Strünker, T.; Kliesch, S.; et al. Motility of efferent duct cilia aids passage of sperm cells through the male reproductive system. Mol. Hum. Reprod. 2021, 27, gaab009. [CrossRef]

113. Danielian, P.S.; Hess, R.A.; Lees, J.A. E2f4 and E2f5 are essential for the development of the male reproductive system. Cell Cycle 2016, 15, 250-260. [CrossRef]

114. Hoque, M.; Chen, D.; Hess, R.A.; Li, F.-Q.; Takemaru, K.-I. CEP164 is essential for efferent duct multiciliogenesis and male fertility. Reproduction 2021, 162, 129-139. [CrossRef]

115. Terré, B.; Lewis, M.; Gil-Gómez, G.; Han, Z.; Lu, H.; Aguilera, M.; Prats, N.; Roy, S.; Zhao, H.; Stracker, T.H. Defects in efferent duct multiciliogenesis underlie male infertility in GEMC1-, MCIDAS- or CCNO-deficient mice. Development 2019, 146, dev162628. [CrossRef]

116. Gaubatz, S.; Lindeman, G.J.; Ishida, S.; Jakoi, L.; Nevins, J.R.; Livingston, D.M.; Rempel, R.E. E2F4 and E2F5 play an essential role in pocket protein-mediated G1 control. Mol. Cell 2000, 6, 729-735. [CrossRef]

117. Johnson, D.G.; Schwarz, J.K.; Cress, W.D.; Nevins, J.R. Expression of transcription factor E2F1 induces quiescent cells to enter S phase. Nature 1993, 365, 349-352. [CrossRef]

118. Timmers, C.; Sharma, N.; Opavsky, R.; Maiti, B.; Wu, L.; Wu, J.; Orringer, D.; Trikha, P.; Saavedra, H.I.; Leone, G. E2f1, E2f2, and E2f3 Control E2F Target Expression and Cellular Proliferation via a p53-Dependent Negative Feedback Loop. Mol. Cell. Biol. 2007, 27, 65-78. [CrossRef] [PubMed]

119. Lalioti, M.-E.; Arbi, M.; Loukas, I.; Kaplani, K.; Kalogeropoulou, A.; Lokka, G.; Kyrousi, C.; Mizi, A.; Georgomanolis, T.; Josipovic, N.; et al. GemC1 governs multiciliogenesis through direct interaction with and transcriptional regulation of p73. J. Cell Sci. 2019, 132, jcs228684. [CrossRef]

120. Danielian, P.S.; Kim, C.F.B.; Caron, A.M.; Vasile, E.; Bronson, R.T.; Lees, J.A. E2f4 is required for normal development of the airway epithelium. Dev. Biol. 2007, 305, 564-576. [CrossRef]

121. Lindeman, G.J.; Dagnino, L.; Gaubatz, S.; Xu, Y.; Bronson, R.T.; Warren, H.B.; Livingston, D.M. A specific, nonproliferative role for E2F-5 in choroid plexus function revealed by gene targeting. Genes Dev. 1998, 12, 1092-1098. [CrossRef]

122. Wallmeier, J.; Al-Mutairi, D.A.; Chen, C.-T.; Loges, N.T.; Pennekamp, P.; Menchen, T.; Ma, L.; Shamseldin, H.E.; Olbrich, H.; Dougherty, G.W.; et al. Mutations in CCNO result in congenital mucociliary clearance disorder with reduced generation of multiple motile cilia. Nat. Genet. 2014, 46, 646-651. [CrossRef] [PubMed]

123. Funk, M.C.; Bera, A.N.; Menchen, T.; Kuales, G.; Thriene, K.; Lienkamp, S.S.; Dengjel, J.; Omran, H.; Frank, M.; Arnold, S.J. Cyclin $\mathrm{O}$ (Ccno) functions during deuterosome-mediated centriole amplification of multiciliated cells. EMBO J. 2015, 34, 1078-1089. [CrossRef]

124. Olle, M.N.; Jung, C.; Terré, B.; Balsiger, N.A.; Plata, C.; Roset, R.; Pardo-Pastor, C.; Garrido, M.; Rojas, S.; Alameda, F.; et al. Constitutive Cyclin O deficiency results in penetrant hydrocephalus, impaired growth and infertility. Oncotarget 2017, 8, 99261. [CrossRef] [PubMed]

125. Ma, C.; Wu, H.; Zhu, D.; Wang, Y.; Shen, Q.; Cheng, H.; Zhang, J.; Geng, H.; Liu, Y.; He, X.; et al. Bi-allelic mutations in MCIDA S and CCNO cause human infertility associated with abnormal gamete transport. Clin. Genet. 2021, 100, 731-742. [CrossRef]

126. Choi, Y.J.; Lin, C.-P.; Ho, J.J.; He, X.; Okada, N.; Bu, P.; Zhong, Y.; Kim, S.Y.; Bennett, M.J.; Chen, C.; et al. miR-34 miRNAs provide a barrier for somatic cell reprogramming. Nat. Cell Biol. 2011, 13, 1353-1360. [CrossRef]

127. Song, R.; Walentek, P.; Sponer, N.; Klimke, A.; Lee, J.S.; Dixon, G.; Harland, R.; Wan, Y.; Lishko, P.; Lize, M.; et al. miR-34/449 miRNAs are required for motile ciliogenesis by repressing cp110. Nature 2014, 510, 115-120. [CrossRef]

128. Yuan, S.; Tang, C.; Zhang, Y.; Wu, J.; Bao, J.; Zheng, H.; Xu, C.; Yan, W. mir-34b/c and mir-449a/b/c are required for spermatogenesis, but not for the first cleavage division in mice. Biol. Open 2015, 4, 212-223. [CrossRef]

129. Bao, J.; Li, D.; Wang, L.; Wu, J.; Hu, Y.; Wang, Z.; Chen, Y.; Cao, X.; Jiang, C.; Yan, W.; et al. MicroRNA-449 and microRNA-34b/c function redundantly in murine testes by targeting E2F transcription factor-retinoblastoma protein (E2F-pRb) pathway. J. Biol. Chem. 2012, 287, 21686-21698. [CrossRef]

130. Concepcion, C.P.; Han, Y.-C.; Mu, P.; Bonetti, C.; Yao, E.; D'Andrea, A.; Vidigal, J.A.; Maughan, W.P.; Ogrodowski, P.; Ventura, A. Intact p53-dependent responses in miR-34-deficient mice. PLoS Genet. 2012, 8, e1002797. [CrossRef]

131. O'Connor, M.G.; Horani, A.; Shapiro, A.J. Progress in diagnosing primary ciliary dyskinesia: The North American perspective. Diagnostics 2021, 11, 1278. [CrossRef] [PubMed] 
132. Graser, S.; Stierhof, Y.-D.; Lavoie, S.B.; Gassner, O.S.; Lamla, S.; Le Clech, M.; Nigg, E.A. Cep164, a novel centriole appendage protein required for primary cilium formation. J. Cell Biol. 2007, 179, 321-330. [CrossRef] [PubMed]

133. Čajánek, L.; Nigg, E.A. Cep164 triggers ciliogenesis by recruiting Tau tubulin kinase 2 to the mother centriole. Proc. Natl. Acad. Sci. USA 2014, 111, E2841-E2850. [CrossRef] [PubMed]

134. Chaki, M.; Airik, R.; Ghosh, A.K.; Giles, R.H.; Chen, R.; Slaats, G.G.; Wang, H.; Hurd, T.W.; Zhou, W.; Cluckey, A.; et al. Exome capture reveals ZNF423 and CEP164 mutations, linking renal ciliopathies to DNA damage response signaling. Cell 2012, 150, 533-548. [CrossRef]

135. Maria, M.; Lamers, I.J.; Schmidts, M.; Ajmal, M.; Jaffar, S.; Ullah, E.; Mustafa, B.; Ahmad, S.; Nazmutdinova, K.; Hoskins, B.; et al. Genetic and clinical characterization of Pakistani families with Bardet-Biedl syndrome extends the genetic and phenotypic spectrum. Sci. Rep. 2016, 6, 34764. [CrossRef] [PubMed]

136. Wheway, G.; Thomas, N.S.; Carroll, M.; Coles, J.; Doherty, R.; Goggin, P.; Green, B.; Harris, A.; Hunt, D.; Jackson, C.L.; et al. Whole genome sequencing in the diagnosis of primary ciliary dyskinesia. BMC Med. Genom. 2021, 14, 234. [CrossRef]

137. Strong, A.; Simone, L.; Krentz, A.; Vaccaro, C.; Watson, D.; Ron, H.; Kalish, J.M.; Pedro, H.F.; Zackai, E.H.; Hakonarson, H. Expanding the genetic landscape of oral-facial-digital syndrome with two novel genes. Am. J. Med. Genet. A 2021, 185, $2409-2416$. [CrossRef] [PubMed]

138. Fujimaru, T.; Kawanishi, K.; Mori, T.; Mishima, E.; Sekine, A.; Chiga, M.; Mizui, M.; Sato, N.; Yanagita, M.; Ooki, Y.; et al. Genetic Background and Clinicopathologic Features of Adult-onset Nephronophthisis. Kidney Int. Rep. 2021, 6, 1346-1354. [CrossRef] 